\title{
PENGEMBANGAN PERANGKAT PRAKTIK LATIHAN PROFESI (PLP) BERBASIS RISET DALAM MENINGKATKAN KOMPETENSI MAHASISWA
}

\author{
Alfian Erwinsyah ${ }^{1}$, Putriani L. Maliki ${ }^{2}$ \\ ${ }^{1,2}$ Institut Agama Islam Negeri Sultan Amai Gorontalo \\ Email: alfian_erwinsyah@iaingorontalo.ac.id
}

\begin{abstract}
ABSTRAK
Tujuan Penelitian ini ialah Untuk menghasilkan profil perangkat Praktik Latihan Profesi berbasis riset Participatory Action Research pada Program Studi Manajemen Pendidikan Islam Fakultas Ilmu Tarbiyah dan Keguruan IAIN Sultan Amai Gorontalo yang valid dan reliable, Untuk mengetahui peningkatan kompetensi manajemen mahasiswa setelah praktikum dengan menggunakan perangkat yang telah dikembangkan, dan untuk mengetahui respon mahasiswa terhadap perangkat yang akan diterapkan serta untuk mengetahui peningkatan kemampuan kompetensi mahasiswa digunakan desain eksperimen kelompok tunggal dengan pretest-postes tatau one group pretest-postest design. Metode yang digunakan adalah jenis penelitian research and development model 4D. Hasil Penelitian yakni Profil perangkat Praktik Latihan Profesi berbasis riset Participatory Action Research yang dihasilkan dalam penelitian ini meliputi: (1) Buku Pedoman PLP, (2) Lembar Observasi, (3) Instrumen Penilaian, (4) Tes Kompetensi Pengetahuan Manajemen Pendidikan berdasarkan hasil validasi menunjukkan bahwa perangkat PLP memenuhi kriteria valid, praktis, dan efektif. Kompetensi Pengetahuan Manajemen Pendidikan mahasiswa Program Studi Manajemen Pendidikan Islam Fakultas Ilmu Tarbiyah Dan Keguruan IAIN Sultan Amai Gorontalo mengalami peningkatan setelah menggunakan perangkat berbasis riset Participatory Action Research dan peningkatannya sudah pada kategori sedang. Respon terhadap perangkat Praktik Latihan Profesi (PLP) berbasis riset Participatory Action Research yang diterapkan umumnya memberikan respon positif.
\end{abstract}

Kata Kunci: Pengembangan Perangkat, PLP, Kompetensi Mahasiswa

\begin{abstract}
The purpose of this study is to produce a profile of the Professional Practice Training tool based on PAR (Participatory Action Research) research at the Islamic Education Management Study Program, Faculty of Tarbiyah and Teacher Training, IAIN Sultan Amai Gorontalo which is valid and reliable, to determine the improvement of student management competence after practicum by using the tool. that has been developed, and to determine student responses to the tools that will be applied and to determine the improvement of student competency skills, a single group experimental design with pretest-posttest or one group pretest-posttest design is used. The method used is a research and development type of $4 D$ model. The results of the study, namely the profile of the Professional Practice Training tool based on Participatory Action Research research produced in this study include: (1) PLP Guidebooks, (2) Observation Sheets, (3) Assessment Instruments, (4) Education Management Knowledge Competency Test based on the validation results show that the PLP device meets the criteria of being valid, practical, and effective. Knowledge Competency in Educational Management of students
\end{abstract}


of the Islamic Education Management Study Program Faculty of Tarbiyah and Teacher Training IAIN Sultan Amai Gorontalo experienced an increase after using a Participatory Action Research research-based tool and the increase was in the moderate category. The response to the Professional Training Practice based on Participatory Action Research research that was applied generally gave a positive response.

Keywords: Development, PLP, College Student Competence

\section{PENDAHULUAN}

Fakultas Ilmu Tarbiyah dan Keguruan (FITK) IAIN Sultan Amai Gorontalo sebagai Lembaga Pendidikan Tenaga Kependidikan (LPTK) mempunyai misi dan tugas menyiapkan serta menghasilkan tenaga kependidikan yang memiliki kompetensi manajerial, kompetensi teknik, kompetensi kepribadian, dan kompetensi sosial. FITK memberikan seperangkat pengetahuan dan keterampilan kepada mahasiswa dalam membentuk kompetensi keguruan dan administrasi melalui program pendidikan prajabatan (preservice program) tentang proses pembelajaran dan atau kegiatan kependidikan lainnya melalui mata kuliah praktikum kependidikan.

Khusus untuk program studi MPI, profil utama lulusannya disiapkan menjadi tenaga kependidikan (tenaga administrasi) pada lembaga pendidikan formal dan berbagai institusi/lembaga yang menangani pendidikan. Sebagai calon tenaga administrasi, lulusan Program Studi MPI diharapkan memiliki kompetensi manajerial, kompetensi teknik, kompetensi kepribadian, dan kompetensi sosial. Dalam menyiapkan tenaga administrasi profesional tersebut, Jurusan/Program Studi MPI FITK IAIN Sultan Amai Gorontalo memberikan seperangkat pengetahuan dan keterampilan kepada mahasiswa Prodi MPI mengenai pengelolaan pendidikan di antaranya pengelolaan sekolah/madrasah melalui Mata Kuliah Praktik Latihan Profesi (PLP) di sekolah/madrasah. Sekolah/Madrasah yang dipilih menjadi lokasi PLP diharapkan dapat membekali mahasiswa sikap, pengetahuan, dan keterampilan mengenai best practice tata kelola sekolah/madrasah. Penempatan mahasiswa Prodi MPI di sekolah/madrasah tempat PLP/magang tersebut dimaksudkan agar mahasiswa MPI mempunyai sikap kerja, pengetahuan, dan keterampilan dalam mengelola sekolah/madrasah.

Secara yuridis, program studi Manajemen Pendidikan Islam (MPI) mengamanatkan bentuk pendidikan profesi mahasiswa menjadi Tenaga Kependidikan yang profesional. Praktikum kependidikan lebih dikenal dengan sebutan Praktik Latihan Profesi atau disebut juga PLP yang dirancang untuk dibagi atas tiga program meliputi; PLP I, PLP II dan PLP III. Program PLP tidak hanya mencakup latihan manajerial, akan tetapi juga termasuk di dalamnya tugastugas menghasilkan karya ilmiah, inilah yang disebut program Participatory Action Research (PAR). Pelaksanaan kegiatannya dikategorikan menjadi tahapan 
yang berbeda, namun secara keseluruhan diarahkan kepada visi unggul dan terkemuka dalam menghasilkan sarjana pendidikan/ tenaga kependidikan. ${ }^{1}$

Isu terkini diperoleh dari Perkumpulan Program Studi MPI se-Indonesia (PPMPI) dan Perkumpulan Manajer Pendidikan Islam Indonesia (Permapendis) mengenai lulusan program studi rumpun manajemen pendidikan akan melalui tes kompetensi untuk masuk pada pendidikan profesi, jika pada profesi guru/pendidik harus melalui PPG, profesi dokter melalui pendidikan profesi dokter, pada profesi tenaga kependidikan/administrasi pun nantinya ada program yang serupa yakni pendidikan profesi yang diawali dengan tes kompetensi manajemen.

Dalam rangka memasuki era disrupsi teknologi dalam revolusi industri 4.0, program studi bertanggung jawab untuk menyiapkan lulusan yang siap bersaing dalam pasar kerja khususnya di bidang manajemen pendidikan/administrasi pendidikan. $^{2}$ Berdasarkan SKL-CPL yang dikeluarkan oleh Diktis Kemenag Tahun 2018 bahwa prodi MPI akan diproyeksikan menjadi tenaga administrasi pendidikan, asisten konsultan pendidikan dan asisten peneliti pendidikan, maka dari itu program studi wajib mempersiapkan lulusan yang ahli dalam kompetensi tersebut yakni memiliki soft skill dan hard skill serta mempunyai ide-ide kreatif, inovatif dan produktif, dengan kegiatan unggulan yakni PLP berbasis PAR. ${ }^{3}$

Atas dasar inilah, peneliti mengusulkan riset pengembangan program studi, dengan judul "Pengembangan Perangkat Praktik Latihan Profesi (PLP) Berbasis Riset PAR (Participatory Action Research) dalam Meningkatakan Kompetensi Mahasiswa Program Studi Manajemen Pendidikan Islam (Studi RnD Model 4D)"

\section{METODE PENELITIAN}

Berdasarkan latar belakang dan rumusan masalah penelitian yang telah dikemukakan, maka jenis penelitian ini merupakan penelitian pengembangan (research and development) menggunakan model 4D yang diadopsi dari Thiagarajan, Semmels dan Smmel meliputi define, design, develop dan disseminate. ${ }^{4}$ Penelitian Pengembangan yang dimaksud adalah penelitian yang dilakukan untuk menghasilkan perangkat Praktik Latihan Profesi berbasis PAR yang meliputi (1) Buku PLP (2) Instrumentasi PLP berupa Lembar Observasi 8 Standar Nasional Pendidikan, dan Lembar Observasi administrasi lainnya, (3) Instrumen Penilaian Kompetensi Teknis, Kompetensi Manajerial, Kompetensi Sosial dan Kompetensi Kepribadian, (4) Tes Kompetensi Manajemen

\footnotetext{
${ }^{1}$ Tim Laboratorium MPI, Pedoman Praktik Latihan Profesi (PLP) Prodi MPI, Bandung: Fakultas Tarbiyah dan Keguruan UIN Sunan Gunung Djati, 2018.

${ }^{2}$ Gunawan, I., dan Benty, D. D. N.. Manajemen Pendidikan: Suatu Pengantar Praktik. (Bandung: Penerbit Alfabeta. 2017), h.17

${ }^{3}$ Soetopo, H. Manajemen Kurikulum dan Pembelajaran. Dalam Imron, A., Maisyaroh, dan Burhanuddin, (Eds.), Manajemen Pendidikan Analisis Substantif dan Aplikasinya dalam Latar Institusi Pendidikan, (Malang: Penerbit Universitas Negeri Malang. 2003), h. 25.

${ }^{4}$ Sudjana. Metode Statistika. (Bandung: Tarsito, 2015), h.56.
} 
Mahasiswa. Untuk mengetahui peningkatan kemampuan kompetensi mahasiswa digunakan desain eksperimen kelompok tunggal dengan pretest-postes tatau one group pretest-postest design. Secara sederhana diagram desain ini sebagai berikut: ${ }^{5}$

$\begin{array}{ccc}\text { Pretest } & \text { Treatment } & \text { Postest } \\ \mathrm{O}_{1} & \mathrm{X} & \mathrm{O}_{2}\end{array}$

Keterangan :

$\mathrm{O}_{1}$ : Observasi atau pengukuran sebelum ada perlakuan

$\mathrm{O}_{2:}$ Observasi atau pengukuran sesudah diberi perlakuan

$\mathrm{X}$ : treatment atau perlakukan, yaitu dengan menggunakan perangkat Praktik Latihan Profesi (PLP) berbasis riset PAR (Participatory Action Research)

Dalam penelitian ini terdapat dua variabel yaitu : Variabel Independen: pengembangan perangkat Praktik Latihan Profesi (PLP) berbasis riset PAR (Participatory Action Research) dan Variabel Dependen: kemampuan kompetensi manajemen mahasiswa.

Subjek dalam penelitian ini adalah seluruh mahasiswa program studi Manajemen Pendidikan Islam angkatan 2017 tahun akademik 2019/2020 yang mengambil MK. Praktik Latihan Profesi (PLP) yakni sebanyak populasi adalah 133 mahasiswa, adapun sampel diambil secara acak dengan teknik simple random sampling dan jumlah sampel ditentukan dengan rumus slovin dihasilkan 99,81 atau dibulatkan menjadi 100 mahasiswa.

Instrumen yang digunakan dalam penelitian ini adalah instrumen yang sudah divalidasi oleh dua validator untuk menilai kesesuaian dengan indikator dan kelayakan penggunaannya. Instrumen yang dikembangkan dalam penelitian ini adalah: (1) lembar observasi SNP, (2) lembar observasi administrasi, (3) angket respon mahasiswa, dan (4) tes kemampuan kompetensi manajemen mahasiswa.

Untuk menganalisis data pada pengembangan perangkat ini akan digunakan teknik analisis statistik deskriptif. Data yang dianalisis adalah sebagai berikut.

\section{Analisis Data Hasil Validasi Perangkat dan Lembar Instrumen Penelitian}

Data hasil validasi para ahli untuk masing-masing perangkat dianalisis dengan mempertimbangkan masukan, komentar dari validator. Hasil analisis tersebut dijadikan sebagai pedoman untuk merevisi perangkat. Adapun kegiatan yang dilakukan dalam proses analisis data kelayakan perangkat yang meliputi

\footnotetext{
${ }^{5}$ Sugiono, Statistika untuk Penelitian. (Bandung: Alfabeta, 2015), h.67.
} 
perangkat (1) lembar observasi SNP, (2) lembar observasi administrasi, dan Buku PLP

Analisis yang digunakan untuk mengetahui tingkat reabilitas oleh dua orang pengamat validator (pada aspek yang sama) pada lembar instrumen perangkat, digunakan digunakan rumus sebagai berikut: ${ }^{6}$

$$
\text { Percentage of Agreement }=\left[1-\frac{A-B}{A+B}\right] \times 100 \%
$$

Keterangan:

$\mathrm{A}=$ hasil penilaian pengamat yang memberikan nilai lebih tinggi

$\mathrm{B}=$ hasil penilaian pengamat yang memberikan nilai lebih rendah

Instrumen dikatakan baik jika mempunyai indeks kesepahaman $\geq 0$,75atau $\geq$ $75 \%$.

\section{Analisis Data Respon Mahasiswa terhadap Perangkat}

Data tentang respon mahasiswa diperoleh dari angket respon mahasiswa terhadap perangkat (buku PLP dan Instrumen Observasi), dan selanjutnya dianalisis dengan persentase. Analisis untuk menghitung persentase banyaknya mahasiswa yang memberikan respon pada setiap kategori yang ditanyakan dalam lembar angket menggunakan rumus sebagai berikut: ${ }^{7}$

$$
P R S=\frac{\sum A}{\sum B} x 100 \%
$$

Keterangan:

PRS = persentase banyak mahasiswa yang memberikan respon positif terhadap kategori yang ditanyakan.

$\sum A=\quad$ banyaknya mahasiswa yang memberikan respon positif terhadap setiap kategori yang ditanyakan dalam angket.

$\sum B=$ banyaknya mahasiswa yang menjadi subjek ujicoba.

Sedangkan kriteria penilaiannya adalah:

$$
\begin{array}{ll}
81 \% \leq \mathrm{x} \leq 100 \% & \text { sangat merespon/sangat setuju(SS) } \\
61 \% \leq \mathrm{x} \leq 80 \% & \text { merespon/ setuju (S) } \\
41 \% \leq \mathrm{x} \leq 60 \% & \text { cukup merespon/ cukup setuju (CS) } \\
21 \% \leq \mathrm{x} \leq 40 \% & \text { tidak merespon/ tidak setuju (TS) } \\
\mathrm{x}<20 \% & \text { sangat tidak merespon(SS) }
\end{array}
$$

Perangkat dikatakan efektif jika sekurang-kurangnya $80 \%$ dari semua mahasiswa menjawab sangat merespon (SS) atau merespon (S) atau rata-rata

\footnotetext{
${ }^{6}$ Meltzer, David E. The relationship between mathematics preparation and conceptual learning gains in physics: a possible .hidden variable. in diagnostic pretest scores. Department of Physics and Astronomy, Iowa State University, Ames, Iowa 50011. 2002.

${ }^{7}$ Trianto. Model Pembelajaran Terpadu. (Jakarta: Bumi Aksara, 2016), h.104
} 
akhir dari skor mahasiswa minimal berada pada kategori merespon (S). ${ }^{8}$

\section{Validitas dan reliabilitas}

\section{a. Uji Validitas}

Uji validitas digunakan untuk mengukur valid tidaknya suatu indikator yang berbentuk angket. Suatu angket dikatakan valid jika pertanyaan mampu untuk mengungkapkan suatu yang akan diukur oleh angket tersebut. Uji validitas angket yang sudah diujicobakan dengan menggunakan rumus Korelasi Person Product Moment. Pengujian menggunakan uji dua sisi dengan taraf signifikansi 0,05 dengan kriteria pengambilan keputusan yaitu jika $r$ hitung $\geq \mathrm{r}$ tabel, maka instrumen dinyatakan valid.

b. Uji Reliabilitas

Suatu alat ukur instrumen disebut reliabel/handal, jika alat tersebut dalam mengukur segala sesuatu pada waktu berlainan, menunjukkan hasil yang relatif sama. Pengukuran reabilitas dapat dilakukan dengan koefisien Alpha Cronbach menggunakan SPSS For Windows dengan kriteria: (a) Bila nilai alpha > 0,6 maka data reliabel; (b) Bila nilai alpha $<0,6$ maka data tidak reliabel.

\section{Analisis Data Peningkatan kompetensi manajemen mahasiswa}

Untuk mengetahui peningkatan kompetensi mahasiswa yang terjadi sebelum dan sesudah penerapan perangkat dihitung dengan rumus gain ternormalisasi ( $N$-gain) sebagai berikut, ${ }^{9}$

$g=\frac{S_{1 \text { total }}-S_{0 \text { total }}}{S_{\text {maks }}-S_{\text {ototal }}}$

Keterangan:

$\mathrm{S}_{\text {0total }}=$ skor total pada tes awal

$S_{1 \text { total }}=$ skor total pada tes akhir

$\mathrm{S}_{\text {maks }}=$ skor maksimum yang mungkin dicapai

Dengan menggunakan rumus $\mathrm{N}$-Gain tersebut maka dapat diketahui seberapa besar peningkatan kemampuan kompetensi manajemen mahasiswa program studi manajemen pendidikan islam secara individu dan secara keseluruhan. Kriteria tingkat $N$-gain adalah sebagai berikut:

Tabel 1. Kategori Tingkat $N$-gain.

\begin{tabular}{cc}
\hline Batasan & Kategori \\
\hline $\mathrm{g}>0,7$ & Tinggi \\
\hline $0,3 \leq \mathrm{g} \leq 0,7$ & Sedang \\
\hline $\mathrm{g}<0,3$ & Rendah \\
\hline
\end{tabular}

${ }^{8}$ Winecoff, H. L. Curriculum Development and Instructional. New York: Addison Wesley Longman, Inc. 2009.

${ }^{9}$ Hake, Richard R. Analyzing Change/Gain Scores. http://list.asu.edu. 1999 


\section{HASIL DAN PEMBAHASAN}

Untuk mendapatkan gambaran hasil penelitian yang telah dilakukan, maka akan diuraikan data hasil penelitian dari proses awal sampai diperoleh hasil penelitian.

\section{Deskripsi Tahap Pengembangan}

Pelaksanaan pengembangan perangkat Praktik Latihan Profesi berbasis PAR dalam Meningkatkan Kompetensi Mahasiswa. Model pengembangan perangkat yang dilakukan dalam penelitian ini berpedoman pada pengembangan perangkat dengan menggunakan model 4D, yang secara garis besarnya meliputi prosedur-prosedur: (1) identifikasi masalah, (2) analisis subjek, (3) analisis materi, , (4) penyusunan instrumen evaluasi, (5) strategi pembelajaran, (6) sumber pelajaran, (7) evaluasi, dan (8) revisi perangkat dan untuk menganalisis data hasil penelitian disesuaikan dengan analisis data yang ditetapkan. Berikut ini dideskripsikan prosedur pengembangan perangkat yang telah dikembangkan dan hasil analisis data yang diperoleh. Dekripsi-deskripsi tersebut dapat dijadikan bahan pertimbangan dalam merevisi perangkat pembelajaran sehingga akhirnya diperoleh perangkat yang berkualitas yaitu valid, praktis, dan efektif. Pengembangan perangkat ang telah dibuat pada penelitian ini terdiri dari.

\section{a. Tahap Penetapan (Define)}

1) Hasil Identifikasi Masalah

Penelitian ini dilaksanakan di Program Studi MPI pada mahasiswa semester VI tahun ajaran 2019/2020. Jumlah sampel penelitian sebanyak 110 mahasiswa. Pada tahap ini dianalisis untuk didentifikasi masalah esensial yang dihadapi oleh program studi MPI dalam meningkatkan kompetensi mahasiswa dalam hal ini pemahaman mahasiswa tentang administrasi pendidikan. Berdasarkan fenomena di lapangan, masalah esensial yang perlu mendapatkan perhatian dalam pelaksanaan PLP adalah:

a) Pelaksanaan Praktik Latihan Profesi selama ini hanya cenderung sebagai pemenuhan kelulusan mata kuliah saja untuk mahasiswa, akibatnya pemahaman tentang administrasi pendidikan oleh mahasiswa belum maksimal.

b) Belum adanya buku panduan PLP, mahasiswa hanya mengandalkan penyampaian materi pada saat pembekalan.

c) Belum lengkapnya instrument kegiatan PLP

Setelah peneliti mengamati proses praktik latihan profesi di Program Studi MPI, peneliti mendapatkan beberapa masalah yang berkaitan perangkat PLP. Peneliti melihat perlunya pengembangan perangkat PLP. Berdasarkan kajian terhadap teori-teori administrasi/manajemen pendidikan, peneliti memilih untuk mengembangkan Buku panduan PLP dan mensematkan perangkat berupa instrument observasi 8 standar nasional pendidikan dan instrument observasi 
administrasi lainnya serta memancing daya logika mahasiswa untuk menemukan masalah mini riset dalam bentuk PAR (Participatory Action Research).

\section{2) Hasil Analisis Mahasiswa}

Analisis mahasiswa dilakukan untuk mengetahui karakteristik mahasiswa yang sesuai dengan rancangan dan pengembangan perangkat. Berdasarkan hasil pengamatan, maka diperoleh beberapa penjelasan tentang karakteristik mahasiswa, adalah rata-rata usia mahasiswa yang menjadi subjek penelitian adalah 21 tahun. Berdasarkan karakteristik di atas, maka mahasiswa di kelas yang menjadi sampel penelitian termasuk homogen atau sama.

\section{3) Hasil Analisis Tugas}

Analisis tugas meliputi analisis tujuan mata kuliah, analisis konsep, dan analisis prosedural. ${ }^{10}$ Analisis tugas dilakukan untuk mengedintifikasi tahaptahap penyelesaian tugas sesuai dengan bahan kajian Praktik Latihan Profesi. Sesuai tujuan standar kompetensi lulusan prodi dan tujuan mata kuliah.

Hasil akhir analisis tugas adalah tertuang dalam Buku PLP dan Lembar Observasi PLP sebagai perangkat yang digunakan dalam penelitian. Analisis tugas yang diimplementasikan dalam buku PLP dan lembar observasi ini, peneliti berpedoman pada SNP dan administrasi pendidikan.

\section{b. Deskripsi Hasil Tahap Perancangan (Design) 1) Penyusunan Instrumen Evaluasi}

Berdasarkan analisis kurikulum, analisis mahasiswa, analisis konsep, seperti yang telah dijelaskan sebelumnya, maka selanjutnya disusunlah instrumen evaluasi dalam hal ini tes kompetensi atau Kompetensi Pengetahuan Manajemen pendidikan. Penyusunan tes ini dimaksudkan untuk mengukur kemampuan pemahaman mahasiswa tentang administrasi pendidikan.

Pada penelitian ini instrumen tes yang digunakan merupakan tes dengan bentuk pilihan ganda didasarkan pada indikator administrasi pendidikan. Instrumen administrasi pendidikan divalidasi konstruk oleh dua validator ahli, setelah divalidasi oleh ahli kemudian dilakukan revisi dan perbaikan berdasarkan saran dari validator. Setelah dilakukan revisi atas saran validator selanjutnya instrumen diujicobakan terbatas kepada 30 responden mahasiswa Program Studi MPI sehingga didapatkan sejumlah soal yang valid dan layak untuk digunakan. Kemudian diaplikasikan pada responden penelitian mahasiswa Program Studi MPI yang telah ditetapkan .

${ }^{10}$ Winecoff, H. L. Curriculum Development and Instructional. New York: Addison Wesley Longman, Inc. . 2009 


\section{2) Hasil Pemilihan Strategi Pembelajaran}

Pada tahap ini dilakukan pemilihan strategi pembelajaran yang sesuai dengan tujuan. ${ }^{11}$ Kegiatan ini meliputi pengembangan model perangkat PLP dengan menggunakan pengembangan model 4D yang didalamnya memuat metode PAR. Dari metode ini masing-masing mahasiswa secara berkelompok diminta untuk menemukan masalah dari program sekolah kemudian mencari tahu kelebihan dan kelemahan serta rekomendasi perbaikan pada saat PLP.

\section{3) Evaluasi}

Pada tahap ini dilakukan evaluasi, berupa pemberian tes Kompetensi Pengetahuan Manajemen pendidikan (pretest dan posttest) pada kelas yang bertujuan memberikan informasi kepada peneliti peningkatan Kompetensi Pengetahuan Manajemen pendidikan pada mahasiswa sebelum dan setelah pelaksanaan PLP Berbasis PAR dengan menggunakan perangkat yang telah dikembangkan.

\section{4) Revisi Perangkat}

Kegiatan revisi dimaksudkan untuk mengevaluasi dan perbaikan rancangan yang telah dibuat. Revisi dilakukan berdasarkan masukan dan penilaian yang diperoleh dari kegiatan evaluasi. Informasi lain diperoleh dari instrumen evaluasi. Proses revisi berjalan paralel dengan awal langkah pengembangan. Langkah ini berhubungan langsung dengan tahapan revisi sehingga hasil yang diperoleh dari suatu tahap dapat segera dilakukan revisi. ${ }^{12}$

Pada tahap revisi ini didahului dengan validasi hasil pengembangan perangkat, yaitu validasi ahli (pakar). Penafsiran pakar merupakan teknik untuk memperoleh masukan dan saran untuk revisi perangkat yang dilakukan oleh tim validasi dan diminta menelaah dan menuntaskan hasil telaah perangkat. Sebelum perangkat diujicobakan kepada subjek penelitian, maka terlebih dahulu dikoreksi oleh validator ahli. Beberapa hal yang disarankan oleh validator dalam revisi perangkat adalah sebagai berikut.

\section{a) Revisi Buku PLP}

Beberapa hal yang menjadi koreksi dari validator ahli terhadap perangkat buku PLP mahasiswa hingga menghasilkan draft akhir yang siap diujicobakan.

b) Revisi Perangkat Lembar Observasi

Beberapa hal yang menjadi koreksi dari validator ahli terhadap perangkat Lembar Kegiatan Mahasiswa (LKPD) hingga menghasilkan draft akhir yang siap diujicobakan.

\footnotetext{
${ }^{11}$ Oliva, P. F. Developing the Curriculum. Boston: Pearson Education, Inc. 2009.

${ }^{12}$ Gunawan, I.. Model of Educational Leadership in the Implementation of Curriculum 2013. Proceedings the 4th International Conference Language, Society, and Culture in Asian Contexts (LSCAC 2016) on Cultivating and Casting Asian Diversities: Empowering the Asians, 24-25 Mei, 2016.
} 
c) Tes Kompetensi Pengetahuan Manajemen pendidikan

Beberapa butir soal yang menjadi koreksi dari validator ahli terhadap Tes Kompetensi Pengetahuan Manajemen pendidikan hingga menghasilkan draft akhir yang siap diujicobakan.

\section{Deskripsi Hasil Pengembangan (Develop)}

Pada tahap pengembangan ini bertujuan menghasilkan perangkat PLP yang telah direvisi sehingga layak digunakan dalam penelitian atau diujicobakan. Kegiatan yang dilakukan pada tahap ini adalah: validasi, simulasi, dan uji coba terbatas. Hasil kegiatan dalam tahap pengembangan menjadi acuan untuk menilai apakah perangkat yang telah dikembangkan memenuhi kriterian valid, efektif, dan praktis.

Bentuk perangkat PLP yang dihasilkan ditinjau dari kriteria valid, praktis, dan efektif adalah sebagai berikut.

a. Hasil Validasi Perangkat

Salah satu kriteria utama untuk menentukan apakah sebuah perangkat layak dipakai atau tidak adalah hasil validasi ahli. Perangkat-perangkat yang digunakan, yaitu: (1) Buku PLP, (2) Lembar observasi, dan (3) Tes Kompetensi Pengetahuan Manajemen pendidikan . Perangkat ini divalidasi oleh dua validator (dosen MPI) . Penilaian para ahli umumnya berupa catatan-catatan kecil pada bagian yang perlu perbaikan. Adapun perangkat yang telah divalidasi dapat dideskripsikan sebagai berikut.

1) Buku PLP

Dalam penyusunan buku panduan, beberapa aspek yang perlu diperhatikan dalam memvalidasi perangkat yakni:

Tabel 2. Rangkuman Hasil Validasi

\begin{tabular}{lc}
\hline No Aspek penilaian & $\bar{x}$ \\
\hline Kelengkapan isi & 3,50 \\
Keluasan isi & 4,00 \\
Kedalaman isi & 4,00 \\
Keakuratan konsep dan teori & 4,00 \\
Keakuratan informasi & 3,50 \\
Kelengkapan Mekanisme & 3,50 \\
Keakuratan istilah & 4,00 \\
Keakuratan notasi, simbol dan ikon & 4,00 \\
Mendorong rasa ingin tahu & 4,00 \\
Kelengkapan lampiran & 3,50 \\
Ketepatan struktur kalimat & 4,00 \\
Keefektifan kalimat & 4,00 \\
Kebakuan istilah & 4,00 \\
Komunikatif & 4,00 \\
\hline
\end{tabular}




\section{Rata-rata total}

3,86

Dari hasil tim validasi pada tabel 4.2 di atas menunjukkan bahwa nilai rata-rata setiap aspek dalam Buku panduan PLP adalah 3,86 dengan koefisien reliabilitas 0,99 .

Dengan demikian buku ini telah memenuhi kriteria layak, namun beberapa aspek telah disarankan oleh validator dan perlu diperhatikan untuk merevisi sebelum digunakan sebagai uji coba yaitu:

a) Cantumkan referensi

b) Buat bagan mekanisme lebih menarik

c) Lampiran dilengkapi

d) perhatikan penulisan kata yang salah (kesalahan pengetikan).

2) Lembar observasi

Dalam menyusun Lembar observasi, beberapa aspek yang perlu diperhatikan dalam memvalidasi perangkat yaitu

Tabel 3. Rangkuman Hasil Validasi

\begin{tabular}{clc}
\hline No. & \multicolumn{1}{c}{ Aspek penilaian } & $\bar{x}$ \\
\hline 1. & Kesesuaian dengan kemampuan mahasiswa & 3,50 \\
2. & Kegiatan yang merangsang mahasiswa & 4,00 \\
3. & Kesesuaian LO dengan Buku dan Tujuan MK & 4,00 \\
4. & Keakuratan isi & 4,00 \\
5. & Keefektifan Tabel & 3,00 \\
6. & Keefektifan kalimat & 3,50 \\
7. & Kebakuan istilah & 4,00 \\
8. & Komunikatif & 4,00 \\
9. & Mendorong berpikir & 4,00 \\
\hline \multicolumn{2}{c}{ Rata-rata total } \\
\hline
\end{tabular}

Tabel di atas menunjukkan bahwa nilai rata-rata setiap aspek pada Lembar Observasi adalah 3,78 dengan koefisien reliabilitas 0,99

Dengan demikian, LO ini telah memenuhi kriteria kevalidan, namun beberapa aspek telah disarankan oleh validator dan perlu diperhatikan untuk merevisi sebelum digunakan sebagai uji coba yaitu:

a. Sesuaikan dengan waktu observasi dan kemampuan mahasiswa,,

b. Perbaiki Tabel,

c. hendaknya mempertimbangan jenis huruf (Font) yang sama untuk semua

d. perhatikan penulisan kata yang salah (kesalahan pengetikan). 
4. Tes Kompetensi Pengetahuan Manajemen pendidikan

Analisis validasi untuk tes Kompetensi Pengetahuan Manajemen pendidikan menggunakan analisis gregory, yang mana kriteria penilaian yang digunakan dalam memvalidasi Tes Kompetensi Pengetahuan Manajemen pendidikan :

a. Indikator sesuai dengan variabel

b. Soal sudah sesuai dengan indikator dan batasan pertanyaan dan jawaban yang diharapkan sudah sesuai

c. Maksud soal dirumuskan dengan singkat dan jelas

d. Rumusan soal menggunakan kata tanya/perintah yang jelas

e. Soal Menggunakan bahasa yang sesuai dengan kaidah bahasa Indonesia yang baku

f. Menggunakan bahasa yang mudah dimengerti dan tidak menggunakan kata/ungkapan yang menimbulkan penafsiran ganda.

Adapun pedoman penskorannya sebagai berikut:

Tabel 4. Pedoman Penskoran validasi tes Kompetensi Pengetahuan Manajemen pendidikan

\begin{tabular}{lc}
\hline \multicolumn{1}{c}{ Kriteria Penskoran } & Skor \\
\hline Semua kriteria dipenuhi & 4 \\
\hline Ada 5-6 kriteria yang dipenuhi & 3 \\
\hline Ada 3-4 kriteria yang dipenuhi & 2 \\
\hline Hanya ada 1-2 kriteria yang dipenuhi & 1 \\
\hline
\end{tabular}

Berdasarkan hasil validasi dari dua pakar menggunakan analisis gregory menunjukkan bahwa koefisien reliabilitas tes Kompetensi Pengetahuan Manajemen pendidikan yang terdiri dari 40 butir soal yakni 0,88 atau berada pada kategori tinggi.

Tes Kompetensi Pengetahuan Manajemen pendidikan ini dapat digunakan dengan sedikit revisi berdasarkan masukan dari validator sebagaimana yang disarankan. Adapun saran validator adalah ada beberapa soal yang perlu direvisi sehingga dapat dikerjakan oleh mahasiswa dan perhatikan kesalahan pengetikan

Berdasarkan analisis hasil validasi perangkat maka dapat disimpulkan bahwa perangkat praktik latihan profesi berbasis PAR yang terdiri dari Buku PLP, Lembar Observasi menurut penilaian ahli telah memenuhi kriteria kevalidan. Hasil validasi perangkat pembelajaran ini dapat digambarkan pada grafik berikut. 


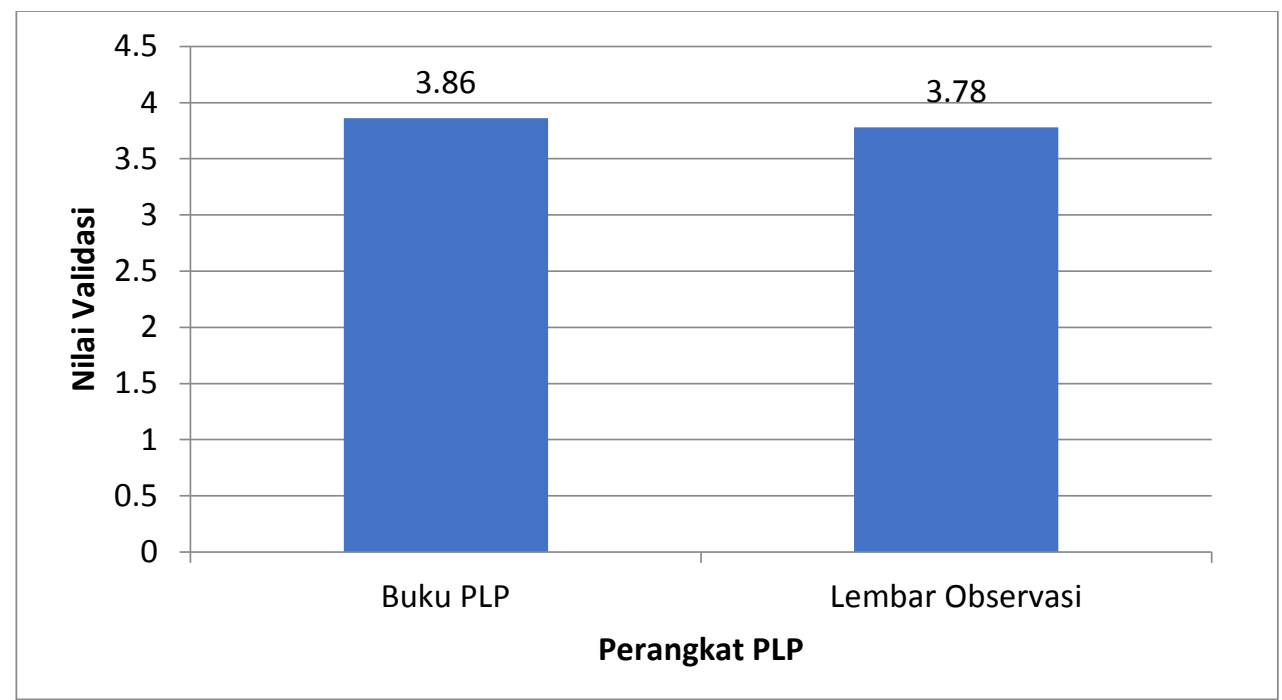

Gambar 1 Diagram Batang Hasil Validasi Ahli tentang Perangkat PLP

\section{Analisis Validitas Butir Tes}

Setelah perangkat instrumen tes divalidasi oleh validator selanjutnya lembar tes tersebut diujicobakan pada mahasiswa kelas VI A Program Studi MPI . Setelah diujicobakan maka dilakukan analisis validitas dan reliabilitas tes.

Berdasarkan analisis validitas butir/item yang menggunakan rumus korelasi Product Moment dan analisis reliabilitas yang menggunakan rumus Kuder dan Richardson (KR-20), maka lembar tes Kompetensi Pengetahuan Manajemen pendidikan yang terdiri dari 40 butir soal pada taraf nyata $\alpha=0.05$, diperoleh 40 butir soal yang dinyatakan valid dan 2 butir soal yang dinyatakan drop. Soal yang dinyatakan valid dan dengan persamaan soal yang valid memiliki derajat kepercayaan (reliabilitas) sebesar $\mathrm{R}=0,96$.

\section{Hasil Respon Mahasiswa}

Analisis respon mahasiswa meliputi respon mahasiswa terhadap proses PLP dan perangkat pembelajaran yang meliputi: buku, lembar observasi, proses praktikum dan bahasa yang dituangkan dalam lembar respon mahasiswa.

Berdasarkan data hasil respon mahasiswa diperoleh bahwa dari sebanyak 30 mahasiswa kelas VI B Program Studi MPI pada umumnya merasa senang terhadap komponen pembelajaran berupa buku mahasiswa, lembar kegiatan mahasiswa, proses pembelajaran, dan bahasa. Sebanyak 90\% mahasiswa memberikan pernyataan positif terhadap buku PLP, $85 \%$ mahasiswa memberikan pernyataan positif terhadap lembar observasi. Serta sebanyak $90 \%$ pernyataan positif terhadap proses PLP.

Berdasarkan kriteria penentuan, dapat disimpulkan bahwa respon mahasiswa terhadap perangkat PLP dan pelaksanaan kegiatan praktikum umumnya memberikan respon positif. Dengan demikian hasil respon mahasiswa 
terhadap perangkat dan pelaksanaan praktikum dapat digambarkan seperti diagram berikut.

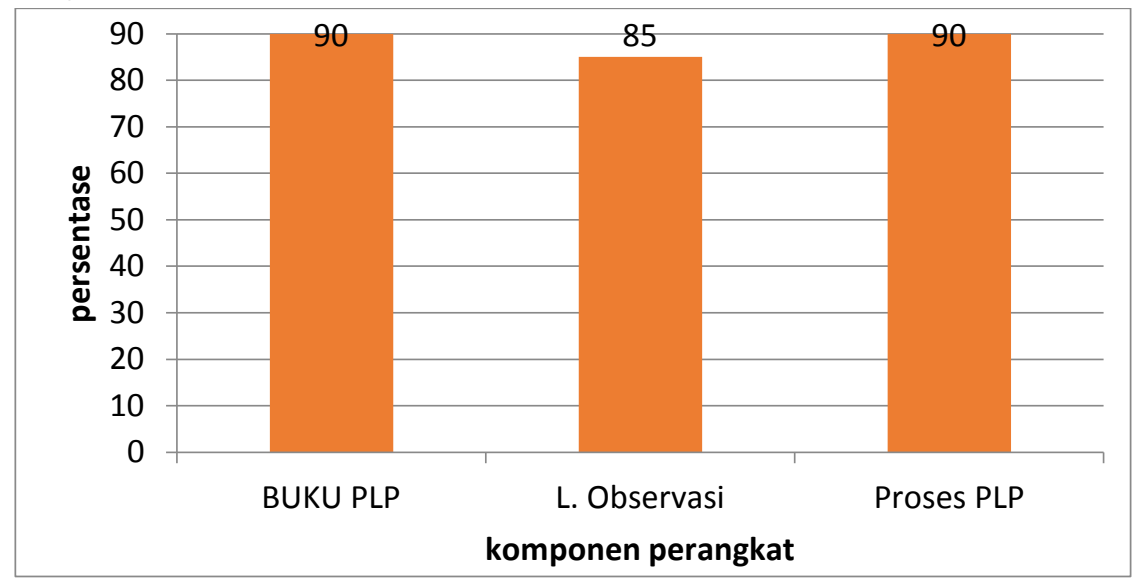

Gambar 2. Diagram Batang Hasil Respon Mahasiswa Terhadap Perangkat dan Pelaksanaan PLP

\section{Tes Kompetensi Pengetahuan Manajemen pendidikan}

a. Analisis deskriptif skor Kompetensi Pengetahuan Manajemen pendidikan

Skor pretes dan postes Kompetensi Pengetahuan Manajemen pendidikan menunjukkan bahwa secara individu sebagian besar mahasiswa mengalami peningkatan kemampuan Kompetensi Pengetahuan Manajemen pendidikan . Dari 100 responden, terlihat bahwa 35 dari mereka mengalami peningkatan skor dan 1 mahasiswa tidak mengalami peningkatan. Rata-rata skor pada pretes hanya 7 meningkat menjadi 11 dari skor maksimal 24.

Statistik skor Kompetensi Pengetahuan Manajemen pendidikan dapat dilihat pada tabel 4.9 Dari tabel tersebut menunjukkan bahwa dari 100 responden, pada pretes terjadi peningkatan nilai Mean dari 7,68 menjadi 22,59, begitu pula dengan median dari 7 menjadi 23. Varians pada pretes 3,57 sedangkan postesnya 9,54. Standar deviasi 1,89 menjadi 3,09 karena rangenya juga berubah dari 11 pada pretes menjadi 19 pada postes.

Tabel. 5. Statistik Skor Kompetensi Pengetahuan Manajemen pendidikan Pretest

\begin{tabular}{|c|c|}
\hline Parameter & Nilai Statistik \\
\hline Subyek & 100 \\
\hline Mean & 7,68 \\
\hline Median & 7 \\
\hline Varians & 3,57 \\
\hline Standar Deviasi & 1,89 \\
\hline Skor Terendah & 3 \\
\hline Skor Tertinggi & 14 \\
\hline
\end{tabular}




\begin{tabular}{|c|c|}
\hline Range & 11 \\
\hline Skor Ideal & 38 \\
\hline
\end{tabular}

Postest

\begin{tabular}{|c|c|}
\hline Parameter & Nilai Statistik \\
\hline Subyek & 100 \\
\hline Mean & 22,59 \\
\hline Median & 23 \\
\hline Varians & 9,54 \\
\hline Standar Deviasi & 3,09 \\
\hline Skor Terendah & 15 \\
\hline Skor Tertinggi & 34 \\
\hline Range & 19 \\
\hline Skor Ideal & 38 \\
\hline & \\
\hline
\end{tabular}

b. Hasil analisis uji Gain

Rata-rata skor pada semua indikator Kompetensi Pengetahuan Manajemen pendidikan dari 100 mahasiswa dapat dilihat pada diagram berikut:

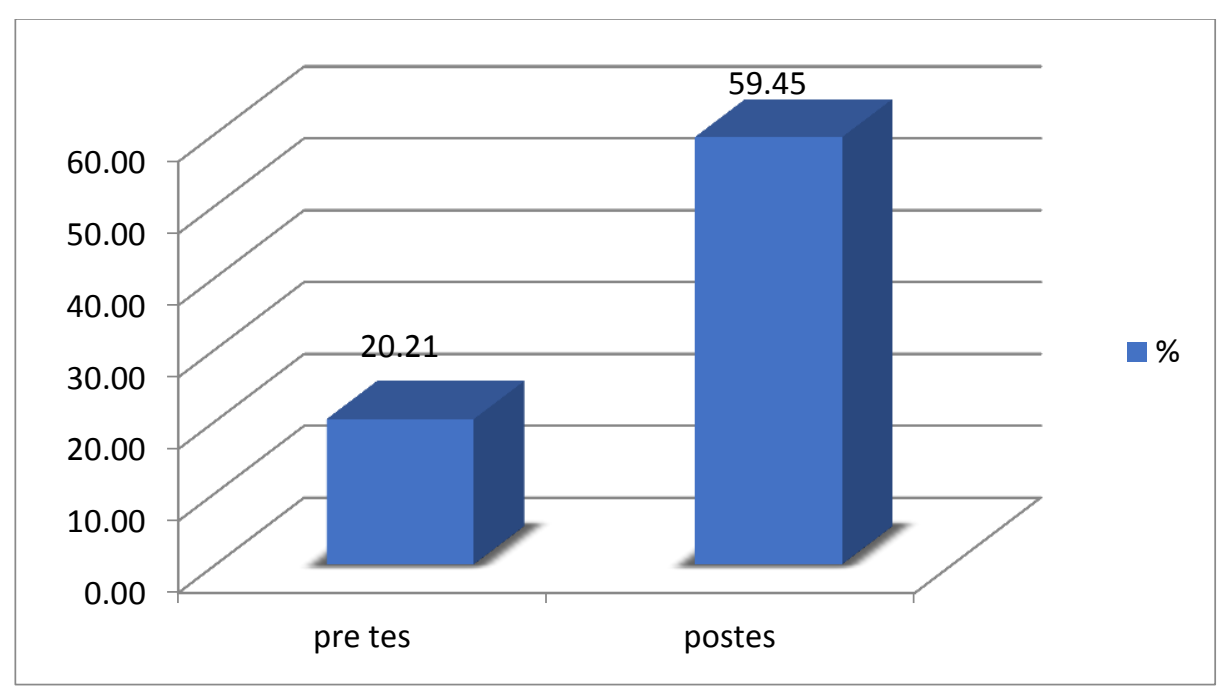

Gambar 3. Diagram batang rata-rata skor pretes dan postes mahasiswa

Pada diagram tersebut dapat dilihat bahwa rata-rata skor pretes adalah 20,21 $\%$ dari skor total dan skor postes adalah 59,45 \% dari skor total, jadi peningkatannya sekitar $39,24 \%$ atau dengan nilai gain 0,49 atau berada pada kategori "sedang".

\section{Pembahasan Hasil Peneltian}

Sebagaimana telah dikemukakan sebelumnya bahwa penelitian ini termasuk ke dalam jenis penelitian pengembangan (research and development) 
yang bertujuan untuk menghasilkan perangkat pembelajaran yang valid, praktis, dan efektif sehingga layak digunakan di program studi Manajemen Pendidikan Islam. Dengan dukungan model berbasis PAR maka kevalidan, kepraktisan dan keefektifan perangkat pembelajaran yang dikembangkan dapat diuraikan berikut ini.

\section{Nilai Kevalidan}

Berdasarkan data hasil penilaian oleh dua validator ahli diperoleh bahwa komponen perangkat PLP memiliki nilai rata-rata validator untuk perangkat, Buku pedoman PLP, Lembar Observasi, Instrumen Penilaian dan Tes Kompetensi Pengetahuan Manajemen pendidikan umumnya berada pada kategori valid/layak. Ini berarti bahwa ditinjau dari aspek penilaian maka perangkat PLP yang dikembangkan maupun Tes Kompetensi Pengetahuan Manajemen pendidikan telah memenuhi kriteria kevalidan.

Hasil penilaian validator menunjukkan bahwa perangkat PLP ditinjau dari keseluruhan aspek sudah dapat dinyatakan valid/layak. Berdasarkan kriteria penilaian yang telah disebutkan sebelumnya diperoleh bahwa nilai rata-rata tersebut berada pada kategori memenuhi semua kriteria, namun masih terdapat saran-saran perbaikan yang perlu diperhatikan untuk kesempurnaan perangkat yang dikembangkan. Setelah dilakukan revisi maka perangkat PLP ini dapat digunakan dalam pelaksanaan PLP.

Hasil validasi instrumen juga menunjukkan bahwa seluruh instrumen yang telah divalidasi berada dalam kategori valid/layak. Hasil ini menunjukkan bahwa instrumen yang telah dirancang dianggap valid/layak untuk dipergunakan sebagai instrumen penilaian atau pengamatan dalam pelaksanaan ujicoba perangkat PLP. Meskipun untuk beberapan instrumen tetap diadakan revisi kecil untuk menyempurnakan draft awal instrumen. Misalnya, pada lembar observasi agar disesuaikan dengan tentative kegiatan PLP.

\section{Kepraktisan Perangkat PLP}

Kepraktisan perangkat pembelajaran yang dikembangkan dapat dilihat dari syarat kevalidan perangkat dan tingkat keterlaksanaan perangkat yang digunakan saat PLP berlangsung. Hasil penilaian validator tentang perangkat PLP dinyatakan telah memenuhi kriteria kevalidan dan telah layak digunakan. Sedangkan secara empirik berdasarkan hasil pengamatan keterlaksanaan perangkat ini pada uji coba dinyatakan sudah memenuhi kriteria kepraktisan.

Dari hasil uji coba diperoleh hasil nilai rata-rata $\mathrm{M}=1,93$. Berdasarkan kriteria penilaian, diperoleh bahwa nilai rata-rata tersebut berada pada kategori terlaksana seluruhnya. Dengan demikian dapat disimpulkan bahwa perangkat PLP yang dikembangkan ini telah memenuhi syarat kepraktisan. Bukti yang dapat ditunjukkan bahwa dari segi pelaksanaan setiap fase dari pelaksanaan PLP mampu dijalankan dengan baik. Dari segi kepraktisannya, perangkat PLP yang 
meliputi Buku pedoman PLP, Lembar Observasi, Instrumen Penilaian dan Tes Kompetensi Pengetahuan Manajemen pendidikan sangat praktis digunakan karena telah merinci kegiatan-kegiatan yang dilakukan oleh mahasiswa dan DPL.

\section{Keefektifan Perangkat PLP}

Beberapa kriteria keefektifan seperti yang telah dikemukakan pada sebelumnya, diperoleh perangkat yang efektif jika dilihat dari beberapa komponen yaitu: (1) Kompetensi Pengetahuan Manajemen pendidikan mahasiswa, (2) respon mahasiswa terhadap terhadap perangkat PLP.

a. Kompetensi Pengetahuan Manajemen pendidikan

Untuk melihat daya serap mahasiswa terhadap pelaksanaan PLP maka dilakukan dengan tes Kompetensi Pengetahuan Manajemen pendidikan . Tes dilakukan sebelum pelaksanaan dan setelah pelaksanaan PLP. Namun demikian, hasil penelitian memperlihatkan tes Kompetensi Pengetahuan Manajemen pendidikan yang telah valid atau layak digunakan setelah divalidasi oleh validator, sudah cukup efektif meningkatkan Kompetensi Pengetahuan Manajemen pendidikan mahasiswa, yakni dapat meningkatkan Kompetensi Pengetahuan Manajemen pendidikan dengan gain 0,49 atau termasuk pada kategori sedang.

b. Respon Mahasiswa

Respon mahasiswa yang diberikan terhadap perangkat pembelajaran diperoleh dengan melihat penilaian mahasiswa terhadap Buku pedoman PLP, Lembar Observasi dan Tes Kompetensi Pengetahuan Manajemen pendidikan. Selain itu mahasiswa diharapkan memberikan penilaian terhadap jalannya PLP dengan menggunakan model PAR serta bahasa yang digunakan. Pada umumnya respon mahasiswa terhadap perangkat pembelajaran adalah sangat positif. Berdasarkan hasil uji coba respon mahasiswa terhadap perangkat pembelajaran diperoleh informasi bahawa secara keseluruhan dapat dikatakan bahwa apresiasi positif mahasiswa terhadap Buku pedoman PLP, Lembar Observasi dan Tes Kompetensi Pengetahuan Manajemen pendidikan, dan model PLP serta bahasa yang digunakan adalah sangat tinggi yang terlihat dari tingginya persentase mahasiswa yang memberikan respon positif yaitu sebesar $90 \%$.

\section{Deskripsi Kompetensi Pengetahuan Manajemen pendidikan}

Berdasarkan analisis deskriptif pada hasil tes Kompetensi Pengetahuan Manajemen pendidikan mahasiswa sebelum dan setelah PLP menunjukkan bahwa secara klasikal tingkat Kompetensi Pengetahuan Manajemen pendidikan mahasiswa mengalami peningkatan dari rata-rata skor 15 menjadi 30 . Peningkatan secara signifikan diperkuat dari hasil penelitian yang menunjukkan bahwa Kompetensi Pengetahuan Manajemen pendidikan mahasiswa program studi MPI Fakultas Ilmu Tarbiyah dan Keguruan IAIN Sultan Amai Gorontalo meningkat setelah menggunakan perangkat PLP model PAR yang dikembangkan. 
Namun peningkatan Kompetensi Pengetahuan Manajemen pendidikan mahasiswa berdasarkan hasil analisis uji gain sebesar 0,49 atau termasuk dalam kategori "sedang".

Dengan terjadinya peningkatan Kompetensi Pengetahuan Manajemen pendidikan, berarti perangkat PLP berbasis PAR memudahkan mahasiswa dalam pelaksanaan PLP. Akan tetapi, peningkatannya masih pada kategori sedang.

\section{KESIMPULAN}

1. Profil perangkat Praktik Latihan Profesi (PLP) berbasis riset PAR (Participatory Action Research) pada Program Studi Manajemen Pendidikan Islam Fakultas Ilmu Tarbiyah Dan Keguruan IAIN Sultan Amai Gorontalo yang dihasilkan dalam penelitian ini meliputi: (1) Buku Pedoman PLP, (2) Lembar Observasi, (3) Instrumen Penilaian, (4) Tes Kompetensi Pengetahuan Manajemen Pendidikan berdasarkan hasil validasi menunjukkan bahwa perangkat PLP memenuhi kriteria valid, praktis, dan efektif.

2. Kompetensi Pengetahuan Manajemen Pendidikan mahasiswa Program Studi Manajemen Pendidikan Islam Fakultas Ilmu Tarbiyah Dan Keguruan IAIN Sultan Amai Gorontalo mengalami peningkatan setelah menggunakan perangkat (PLP) berbasis riset PAR (Participatory Action Research) dan peningkatannya sudah pada kategori sedang..

3. Respon terhadap perangkat Praktik Latihan Profesi (PLP) berbasis riset PAR (Participatory Action Research) yang diterapkan umumnya memberikan respon positif.

\section{DAFTAR PUSTAKA}

Gunawan, I.. Model of Educational Leadership in the Implementation of Curriculum 2013. Proceedings the 4th International Conference Language, Society, and Culture in Asian Contexts (LSCAC 2016) on Cultivating and Casting Asian Diversities: Empowering the Asians, 24-25 Mei, 2016.

Gunawan, I. Instructional Management in Indonesia: A Case Study. Journal of Arts, Science and Commerce, 8(1). 2017.

Gunawan, I., dan Benty, D. D. N.. Manajemen Pendidikan: Suatu Pengantar Praktik. Bandung: Penerbit Alfabeta. 2017

Hake, Richard R. Analyzing Change/Gain Scores. http://list.asu.edu. 1999

Meltzer, David E. The relationship between mathematics preparation and conceptual learning gains in physics: a possible .hidden variable. in diagnostic pretest scores. Department of Physics and Astronomy, Iowa State University, Ames, Iowa 50011. 2002.

Sudjana. Metode Statistika. Bandung: Tarsito. 2015.

Sugiono, Statistika untuk Penelitian. Bandung: Alfabeta, 2015. 
Tim Laboratorium MPI, Pedoman Praktik Latihan Profesi (PLP) Prodi MPI, Bandung: Fakultas Tarbiyah dan Keguruan UIN Sunan Gunung Djati, 2018.

Trianto. Model Pembelajaran Terpadu. Jakarta: Bumi Aksara, 2016.

Undang-Undang Nomor 14 Tahun 2005 Tentang Guru dan Dosen.

Hamalik, O.. Pengembangan Kurikulum: Dasar-dasar dan Pengembangannya. Bandung: Mandar Maju. 2004

Hidayat, A., dan Machali, I. Pengelolaan Pendidikan. Bandung: Pustaka Educa. 2013.

Oliva, P. FDeveloping the Curriculum. Boston: Pearson Education, Inc. . 2009.

Soetopo, H. Manajemen Kurikulum dan Pembelajaran. Dalam Imron, A., Maisyaroh, dan Burhanuddin, (Eds.), Manajemen Pendidikan Analisis Substantif dan Aplikasinya dalam Latar Institusi Pendidikan (hlm. 25-42). Malang: Penerbit Universitas Negeri Malang. 2003.

Winecoff, H. LCurriculum Development and Instructional. New York: Addison Wesley Longman, Inc. . 2009. 